\title{
Exploratory Examination of Relationships between Learning Styles and Learner Satisfaction in Different Course Delivery Types
}

\author{
S. Michelle Cox \\ Dreeben School of Education, University of the Incarnate Word \\ 4301 Broadway, San Antonio, Texas 78209, USA \\ E-mail: smcox1@uiwtx.edu \\ Kuan Chen Tsai (Corresponding author) \\ Dreeben School of Education, University of the Incarnate Word \\ 4301 Broadway, San Antonio, Texas 78209, USA \\ E-mail: ktsai@student.uiwtx.edu
}

Received: June 9, 2013 Accepted: June 27, 2013 Published: August 8, 2013

doi:10.5296/ijssr.v1i1.4100 URL: http://dx.doi.org/10.5296/ijssr.v1i1.4100

\begin{abstract}
Many scholars have underscored the importance of recognizing the variety of students' learning preferences and then adapt appropriate teaching strategies to fit this variance in order to create an optimal learning situation for most students in classes. The purpose of this study was to identify which of the learning preferences would be related to learner satisfaction. Two major findings were found. First, the learning preferences of this sample showed that most of students were balanced learners in the Active-Reflective and the Sequential-Global dimensions. Second, the regression analysis indicated that the Sensing-Intuitive dimension was the strongest predictor of students' learning satisfaction.
\end{abstract}

Keywords: Learning styles, learning satisfaction, adult learners 


\section{Introduction}

Adult students learn in different ways, so it is expected that teaching methods should also vary. Felder and Silverman (1988) stated that "how much a given student learns in a class is governed in part by that student's native ability and prior preparation but also by the compatibility of his or her learning style and the instructor's teaching style" (p. 674). Brookfield (1986) stated, "praxis is placed at the heart of effective facilitation. Learners and facilitators are involved in a continual process of activity, reflection upon activity, collaborative analysis, and so on" (p. 10). Most important, instructors should recognize the variety of students' learning preferences and adapt their teaching strategies to fit this variance in order to create an optimal learning situation for most students in classes (Felder \& Silverman, 1988). As Felder and Spurlin (2005) pointed out, it is possible that when learning styles and teaching styles are seriously mismatched, students' academic performance might not attain the expected outcomes.

Heimlich and Norland (2002) identified five elements that are important for teaching-leaning context: teacher, learner, group, content, and environment. They further argued, "the purpose of teaching is to enhance learning" (p. 18). As a result, it is important to use different techniques and strategies in order to satisfy the variety of learning styles. The assumption is grounded in the fact that "there is no single correct method for any teaching style" (p. 21) and thus it is beneficial for an educator employing various methods and techniques to match learning preferences of students. For adult learners, because of increasing complex life experiences, the needs for flexible teaching styles and planning are more crucial to accommodate adults' differing ways of learning (Brundage, Keane, \& Mackneson, 1994).

With time being a constraint for many adults that are seeking to complete their education, some have chosen to take online or blended classes to balance their ability to attend class with the challenges of work and family life. However, Merriam, Caffarella, and Baumgartner (2007) cautioned, "the promise of convenience and ease (for a price) may fool some students in terms of the commitment involved and the independent learning skills needed" (p. 41). One of the authors of this paper has found that first time students in the online classes have contacted her because they expected that the content would be reduced in an online format, as well as having less assignments due during the semester. There is also discussion of online learning "widening the gap between the haves and the have-nots" (Merriam et al., 2007, p. 40). This is thought to be caused by the digital divide that occurs as well as economic constraints. Blended and online learning requires that students have the capability of maneuvering through the online "classroom", the video assignments, and the use of simulations; all which may be using different technological platforms. MacKeracher (2012) also found that ergonomics of learning at home, work, or while traveling may result in eyestrain and injury.

A number of studies have been investigated student learning styles in different contexts, including mathematics (Akib, 2013), pharmacy (Crawford, Alhreish, \& Popovich, 2012), EFL (English as a foreign language, Weng, 2012), health science (Manee, Nadar, \& Jahrami, 2013), secondary schoolchildren (Ogundokun, 2011), medical students (Nuzhat, Salem, 
Hamdan, \& Ashour, 2013), business students (Ramayah, Sivanandan, Nasrijal, Letchumanan, $\&$ Lim Chee, 2009), and online-learning (Shaw, 2012). This survey of literature clear implies that the importance of learning styles of students for educators and practitioners to evaluate the appropriateness of pedagogies and curricula. Without doubt, teachers should be aware of their students' learning preferences and make proper adjustments to fit their styles, thereby maximizing learning outcomes.

The aim of this study is exploratory and practical in nature. It is believed that identifying any strong relationships between learning styles and learner satisfaction within the context of different types of classroom delivery will contribute to improving instruction through providing course delivery strategies tailored to different learning preferences, realizing that not all types of classrooms will be satisfactory for every student. The three types that were examined are virtual/online, blended (half of the class time is face to face and half of the class time is facilitated online), and face to face. As a consequence, the purpose of the current study was to identify which (if any) of the cognitive learning dimensions on the Index of Learning Styles (ILS; Felder \& Soloman, 1997) would be related to learner satisfaction in different types of course delivery.

\section{The Models of Learning Styles}

"Learning style is sometimes defined as the characteristic cognitive, affective, social, and psychological behaviors that serve as relatively stable indicators of how learners perceive, interact with, and respond to the learning environment" (MacKeracher, 2012, location 1498). Sternberg (1997) pointed out the difference between styles and abilities: "A style is a preferred way of thinking. It is not an ability, but rather how we use the abilities we have. We do not have a style, but rather a profile of styles" (p. 19). As an educator, the professor needs to recognize the students' learning and thinking styles in an attempt to match teaching styles to their learning styles. In fact, "many of the students we are consigning to the dust heaps of our classrooms have the abilities to succeed. It is we, not they, who are failing. We are failing to recognize the variety of thinking and learning styles they bring to the classroom, and teaching them in ways that don't fit them well”' (p. 17).

MacKeracher (2012) believed that "most cognitive styles are understood as ranging across paired behaviors (bipolar) with opposing poles being perceived as occupying opposite ends of a behavioral continuum" (location 1528-1535). According to the literature of learning styles, several scholars have proposed and developed learning models to explain the learning needs of students, including the Myers-Briggs Type Indicator (MBTI; Lawrence, 1994), the Kolb's learning style model (Kolb, 1984), the Herrmann Brain Dominance Instrument (HBDI; Herrmann, 1990), and the Felder-Silverman learning model (Felder \& Silverman, 1988). The MBTI framework identifies four ranges of classifications: (a) extroverts or introverts, (b) sensors or intuitors, (c) thinkers or feelers, and (d) judgers or perceivers. Kolb's model classifies students as having a learning preference, of which there are four types: (a) concrete experience and reflective observation, (b) abstract conceptualization and reflective observation, (c) abstract conceptualization and active experimentation, and (d) concrete experience and active experimentation. The model HBDI identifies four modes based on the 
function of the brain, including (a) left brain, cerebral: logical and critical; (b) left brain, limbic: sequential and organized; (c) right brain, limbic: emotional and interpersonal; and (d) right brain, cerebral: visual and holistic.

The Felder-Silverman learning model classifies different learning modes. It includes (a) sensing or intuitive learners, (b) visual or verbal learners, (c) inductive or deductive learners, (d) active or reflective learners, and (e) sequential or global learners. Felder and Soloman (1997) then developed the inventory, Index of Learning Styles (ILS), and is used for identifying different learning styles. This instrument measures learning styles on four bipolar dimensions related to the preference for the type of information perceived (sensory to intuitive), the modality by which that sensory information is most effectively perceived (visual to verbal), the manner in which it is processed (active to reflective), and the manner in which a learner progresses toward understanding (sequential to global; Felder \& Silverman, 1988). More specifically, the four bipolar dimensions are the following: (a) sensing (concrete thinker) versus intuitive (abstract thinker); the S-N dimension; (b) visual (prefers visual presentations) versus verbal (prefers written and spoken explanations); the $\mathrm{Vs}-\mathrm{Vb}$ dimension; (c) active (prefers working in groups) versus reflective (prefers working alone); the A-R dimension; and (d) sequential (linear thinking) versus global (holistic thinking); the Sq-G dimension (Felder \& Spurlin, 2005, p. 103).

The development of these models plays dual roles. As Felder and Silverman (1988) observed, "a learning-style model classifies students according to where they fit on a number of scales pertaining to the ways they receive and process information" (p. 674). On the other hand, it also implies that the development of a "teaching-style model . . . classifies instructional methods according to how well they address the proposed learning style components" (p. 674). Therefore, "most of the learning and teaching style components parallel one another" (Felder \& Silverman, 1988, p. 674).

A number of educators have applied the foregoing four models in educational settings. Most important, based on the investigation, educators could design better curriculum for improved teaching and learning (Du Torr, De Boer, Bothma, \& Scheepers, 2012; Felder, Felder, \& Dietz, 2002; Felder \& Henriques, 1995; Palermo, Walker, Brown, \& Zogi, 2009). Felder and Spurlin (2005) argued that the most important implication of learning styles is grounded in designing effective teaching strategies and instruction. As a consequence, they stated,

The optimal teaching style is a balanced one in which all students are sometimes taught in a manner that matches their learning style preferences, so they are not too uncomfortable to learn effectively, and sometimes in the opposite manner, so they are forced to stretch and grow in directions they might be inclined to avoid if given the option. (p. 105)

According to the Felder-Silverman model, Felder and Silverman (1988) encouraged teachers to include several techniques to address all learning styles: (a) motivate learning; (b) provide 
a balance of concrete information and abstract concepts; (c) balance material that emphasizes practical problem-solving methods with material that emphasizes fundamental understanding; (d) provide explicit illustrations of intuitive patterns and sensing patterns; (e) provide concrete examples of the phenomena the theory describes and then develop the theory or formulate the model; (f) do not fill every minute of class time instead providing intervals for students to think; (g) assign some drill exercises to provide practice in the basic methods being taught but do not overdo them; (h) give students the option of cooperating on homework assignments to the greatest possible extent; (i) applaud creative solutions, even incorrect ones; and (j) talk to students about learning styles, both in advising and in classes ( $p$. $680)$.

In addition, Felder (1996) provided some suggestions for teachers to maximize the effects of learning: (a) teach theoretical material by first presenting phenomena and problems that relate to the theory; (b) balance conceptual information with concrete information; (c) make extensive use of sketches, plots, schematics, diagrams, and physical demonstration in addition to oral and written explanations and derivations in lecture and readings; (d) occasionally give some experimental observations before presenting the general principle; (e) provide class time for students to think about the material being presented and for active student participation; (f) encourage or mandate cooperation on homework; and (g) demonstrate the logical flow of individual course topics, but also point out connections between the current material and other relevant material in the same areas (pp. 22-23). Finally, Felder (1996) suggested each model has its face value and concluded that "a learning style model is useful if balancing instruction on each of the model dimensions meets the learning needs of essentially all students in a class" (p. 23).

\section{Method}

\subsection{Design}

A cross-sectional survey method was used for this study. The data were collected for the last week of the semester by using two instruments though Survey Monkey. Because of availability of target subjects, this pilot study only recruited a small sample for explore possible relationships between learning styles and learning satisfaction. Independent variables for this investigation were four bi-polar LSI scales (A-R, S-N, Vs-Vb, and Sq-G) and dependent variables were learning satisfaction (instructor, material, active learning, and interaction).

\subsection{Subjects}

A convenient sampling with four classes drawn from a population of undergraduate and graduate students within a southwest private university was used: two virtual graduate classes (five students from Adult Learning; 15 students from Foundations of Organizational Development), one face to face undergraduate class (11 students from Teambuilding), and one blended undergraduate class (16 students from Human Resource Management). A total of 47 students ( 31 females) were recruited from the adult degree courses. All of these students have returned to school to complete their degrees as adults with working experience. Subjects 
within each group self-selected to respond to the survey. The voluntary participants were offered extra credits added to their final grade for the course. The majority was in the age group of 35 to 44 (19 students) and Hispanics (31 students) with a mean score of GPA at 3.47 $(S D=.39)$.

\subsection{Instrument}

\subsubsection{The Index of Learning Styles (ILS)}

The ILS is a 44-question instrument designed to evaluate learning preferences based on four dimensions of the Felder-Silverman framework. Each learning style has associated with it 11 items with two options (a or b), representing one or the other category of the dimension (e.g., sensing or intuitive). The purpose of this dichotomous structure is to force participants to make a decision between the two options, thereby avoiding ambiguity and increasing the chance to detect preferences.

With regard to validity and reliability of ILS, Felder and Spurlin (2005) examined several studies using the ILS and reported adequate information for supporting the validity and reliability of this construct. Litzinger, Lee, Wise, and Felder (2007) reexamined the reliability, factor structure, and construct validity of the ILS by using random samples of 1000 students from three colleges. They concluded that the ILS "generates data with acceptable levels of internal consistency reliability, and that evidence for its construct validity from both factor analysis and student feedback is strong" (p. 316). Moreover, several advantages of using this instrument as an evaluation tool of individual learning preferences are the following: (a) it is a free web-based questionnaire, (b) it has an automatic reporting feature, and (c) it has accompanying descriptive information provided by the authors. Cronbach's coefficient alpha revealed that the dimensions $\mathrm{S}-\mathrm{N}, \mathrm{Vs}-\mathrm{Vb}, \mathrm{A}-\mathrm{R}$, and $\mathrm{Sq}-\mathrm{G}$ were $0.739,0.612,0.445$, and 0.497, respectively. However, it is important to note that this conclusion of internal reliability is not consistent with other studies (Litzinger et al., 2007).

\subsubsection{Learner Satisfaction}

This section included 16 statements. Responses were solicited using a 5- point Likert-type scale, ranging from "strongly disagree" (1) to "strongly agree." (5) The purpose of this part was to investigate students' stratification of learning, the course, and the instructor. One of the example of this survey was "I am satisfied with my learning outcomes." Cronbach's coefficient alpha was .908 , which attained a high internal consistent reliability.

\subsection{Procedure}

The instructor-researcher informed all students at the beginning of the semester that a research study would be conducted during the semester based on a survey that measures their learning styles and their attitudes on the experience of the course. In addition, they were informed that if they take part in this study, they would gain extra credit for the class. In the last two weeks of the semester, one of the researchers (not the instructor) sent the informed consent form and the survey to students by Survey Monkey.

One of the researchers (not the instructor of the courses) performed the coding of the data. 


\section{Macrothink}

Data were confidential in that subject ID codes were assigned. No master list was created. No personal identifying information was associated with the ID codes. The participants were provided with a link to Survey Monkey. Completed questionnaires were collected by the researcher who coded the data. The researcher only informed the instructor of who turned in the survey so that students would receive the extra credit for the class. By putting in a "wall" between the two researchers, it could minimize the researcher-instructor interaction with the data so that there was no bias to student evaluation. Reports from the data were in the aggregate. Each of the subject's scores on each of the four bi-polar LSI scales then were re-coded so that scores range on an equivalent scale from +11 to -11 . Next, there was an examination of the survey regarding the course delivery. These items were examined for potential correlation.

\section{Results}

Table 1 shows the characteristics of learning styles in 47 students. The majority of students had balanced learning preferences in the A-R dimension and the Sq-G dimension. In the S-N dimension, the number of students across three categories was fairly equal, while in the $\mathrm{Vs}-\mathrm{Vb}$ dimension the number of students between balanced and moderate preferences was only fairly equal.

Table 1. Learning preferences of 47 students

\begin{tabular}{|c|c|c|c|c|c|}
\hline & Balanced & Moderate & Strong & & \\
\hline Dimension & $n(\%)$ & $n(\%)$ & $n(\%)$ & $\chi^{2}(2)$ & $p$ \\
\hline A-R & $33(70.2)$ & $11(23.4)$ & $3(6.4)$ & 30.809 & $<.001$ \\
\hline S-N & $17(36.2)$ & $17(36.2)$ & $13(27.7)$ & .681 & .711 \\
\hline Vs-Vb & $18(38.3)$ & $21(44.7)$ & $8(17)$ & 5.915 & .052 \\
\hline $\mathrm{Sq}-\mathrm{G}$ & $28(59.6)$ & $16(34)$ & $3(6.4)$ & 19.957 & $<.001$ \\
\hline \multicolumn{6}{|c|}{$\begin{array}{l}\text { Note. A-R, Active-Reflective; S-N, Sensing-Intuitive; Vs-Vb, Visual-Verbal; Sq-G, } \\
\text { Sequential-Global. }\end{array}$} \\
\hline
\end{tabular}

The varimax-rotated component factor analysis was utilized to the section of 16 items learner satisfaction and four factors (instructor, material, active learning, and interaction) were extracted as shown in Table 2. Mean scores of most of items were over four ( $S D$ from .562 to .862 ). 
Table 2. Learner satisfaction

\begin{tabular}{|c|c|c|}
\hline Item & $M$ & $S D$ \\
\hline Factor 1: Instructor & 4.41 & .575 \\
\hline I am willing to take another course taught by this instructor. & 4.51 & .655 \\
\hline I am satisfied with the instructor. & 4.47 & .654 \\
\hline The instructor stimulates my interest in this course. & 4.32 & .862 \\
\hline The instructor is supportive and responsive to my any questions. & 4.51 & .621 \\
\hline The instructor will respond to all of my emails. & 4.45 & .717 \\
\hline My expectations of this course are satisfied. & 4.21 & .690 \\
\hline Factor 2: Material & 4.31 & .488 \\
\hline The syllabus is clear and relevant to the course objective. & 4.45 & .653 \\
\hline $\begin{array}{l}\text { The materials (e.g., video \& extra reading) used in this course are helpful for my } \\
\text { learning. }\end{array}$ & 4.30 & .657 \\
\hline The textbook is appropriate for this course and supports my learning. & 4.34 & .562 \\
\hline I am satisfied with my learning outcomes. & 4.30 & .548 \\
\hline The workload demands for this course are appropriate. & 4.15 & .722 \\
\hline Factor 3: Active learning & 4.18 & .555 \\
\hline I feel interested in this course. & 4.45 & .653 \\
\hline I like to spend extra time on this course. & 3.72 & .800 \\
\hline I make progress with this course. & 4.36 & .605 \\
\hline Factor 4: Interaction & 4.16 & .600 \\
\hline I actively take part in classroom interaction. & 4.15 & .589 \\
\hline I actively take part in classroom discussion. & 4.17 & .670 \\
\hline
\end{tabular}

A Pearson correlation coefficient was calculated for the relationship among ten variables in the survey. A moderate positive correlation was found between the S-N dimension and the Sq-G dimension, while a negative correlation was with the satisfaction of instructor, material, and overall. They were all significant. A significant correlation between the $\mathrm{Vs}-\mathrm{Vb}$ dimension and the interaction was also found and this relationship was moderate and negative. Another significant moderate and negative correlation was between the Sq-G dimension and the instructor and overall satisfaction. The correlations among four factors of learning 
satisfaction were all significant and positive, ranging from moderate to strong; however, only the relationship between the instructor and the interaction was not significant.

Table 3. Intercorrelations among ten measures of learning preferences and satisfaction

\begin{tabular}{|c|c|c|c|c|c|c|c|c|c|c|}
\hline Measure & 1 & 2 & 3 & 4 & 5 & 6 & 7 & 8 & 9 & 10 \\
\hline 1.GPA & -- & & & & & & & & & \\
\hline 2.A-R & -.046 & -- & & & & & & & & \\
\hline 3.S-N & -.121 & -.101 & -- & & & & & & & \\
\hline 4.Vs-Vb & -.218 & .023 & .116 & -- & & & & & & \\
\hline 5.Sq-G & -.047 & -.237 & $.550 * *$ & -.101 & -- & & & & & \\
\hline 6.Instructor & -.213 & .096 & $-.397 * *$ & .067 & $-.344^{*}$ & -- & & & & \\
\hline 7.Material & -.240 & -.085 & $-.341^{*}$ & -.133 & -.226 & $.618 * *$ & -- & & & \\
\hline 8.Active learning & -.110 & .056 & -.249 & -.157 & -.220 & $.602 * *$ & $.565 * *$ & -- & & \\
\hline 9.Interaction & .180 & .050 & -.150 & $-.310 *$ & -.156 & .084 & $.409 * *$ & $.316^{*}$ & -- & \\
\hline $\begin{array}{l}\text { 10.Overall satisfaction } \\
* p<.05 . * * p<.01 \text {. }\end{array}$ & -.185 & .040 & $-.402 * *$ & -.104 & $-.330 *$ & $.872 * *$ & $.846^{* *}$ & $.791 * *$ & $.433 * *$ & -- \\
\hline
\end{tabular}

The results of the one-way ANOVA in the Table 4 indicates that on two variables of leaning satisfaction were significant differences among four different classes. A significant difference was found about the satisfaction of instructor and overall satisfaction, $F(3,43)=5.86, p$ $=.002, F(3,43)=3.61, p=.021$, respectively. Tukey's $H S D$ was used to determine the nature of the differences. This analysis revealed that students who participated in the Adult Learning class scored significantly lower $(M=3.57, S D=0.62$ for instructor; $M=3.76, S D=$ 0.28 for overall) than students who were in the other three classes.

Table 4. Means, standard deviations, and one-way ANOVA for four classes and satisfaction

\begin{tabular}{lcccccc}
\hline & Teambuilding & $\begin{array}{c}\text { Human } \\
\text { Resource }\end{array}$ & $\begin{array}{c}\text { Adult } \\
\text { Learning }\end{array}$ & $\begin{array}{c}\text { Organizational } \\
\text { Development }\end{array}$ & & \\
\hline Variable & $M(S D)$ & $M(S D)$ & $M(S D)$ & $M(S D)$ & $F(3,43)$ & $p$ \\
Instructor & $4.59(0.46)$ & $4.58(0.41)$ & $3.57(0.62)$ & $4.41(0.58)$ & 5.86 & .002 \\
Material & $4.53(0.43)$ & $4.28(0.50)$ & $3.92(0.30)$ & $4.31(0.51)$ & 1.93 & .139 \\
Active learning & $4.30(0.50)$ & $4.29(0.57)$ & $3.60(0.43)$ & $4.16(0.53)$ & 2.43 & .078 \\
Interaction & $4.05(0.52)$ & $4.00(0.75)$ & $4.20(0.45)$ & $4.40(0.47)$ & 1.35 & .270 \\
Overall & $4.45(0.35)$ & $4.36(0.44)$ & $3.76(0.28)$ & $4.32(0.42)$ & 3.61 & .021 \\
satisfaction & & & & & & \\
\hline
\end{tabular}

In order to further understand which learning preference could predict the overall satisfaction of learning from students, a stepwise multiple regression was performed with four dimensions as predictors (A-R, S-N, Vs- Vb, and $\mathrm{Sq}-\mathrm{G}$ ) and the overall satisfaction was served as the dependent variable. This sequential search method shows that only S-N dimension was the greatest contribution of the independent variable in the regression model 
and other three dimensions were excluded to developing the equation. As Table 5 displays, the regression was significant different from zero, $F(1,45)=8.68, p=.005$, with $R^{2}$ at .16 and the adjusted $R^{2}$ value of .14 indicates that about $15 \%$ of the variability in learning satisfaction was predicted by S-N dimension. Most importantly, the regression coefficient shows that the stronger preference of the $\mathrm{S}-\mathrm{N}$ dimension, the less satisfaction of learning.

Table 5. Regression analysis summary for four dimensions predicting satisfaction of learning

\begin{tabular}{lccccc}
\hline Variables entered & $B$ & $95 \%$ CI & B & $t$ & $p$ \\
\hline Constant & 4.377 & {$[4.25,4.51]$} & & 68.56 & $<.001$ \\
S-N & -.034 & {$[-.06,-.01]$} & -.402 & -2.95 & .005 \\
Variables not entered & Beta in & Partial correlation & $t$ & $p$ \\
Vs-Vb & -.058 & -.063 & -.421 & .676 \\
$\mathrm{Sq}-\mathrm{G}$ & -.156 & -.142 & -.953 & .343 \\
$\mathrm{~A}-\mathrm{R}$ & -.001 & -.001 & -.006 & .995 \\
Note. $R^{2}=.162$ (Adjusted & $R^{2}=.143$ ). A-R, Active-Reflective; S-N, Sensing-Intuitive; Vs-Vb, \\
Visual-Verbal; Sq-G, Sequential-Global. & &
\end{tabular}

\section{Discussion}

Before further discussion, several limitations of this study should be noted. First, the nature of this pilot study is exploratory and based on only 47 adult students from one institution with one professor. Therefore, the results of this study cannot be generalized for populations of all ages and at different institutions. Second, the internal reliability of the $\mathrm{Vs}-\mathrm{Vb}$, the A-R, and the Sq-G dimension were quite low. Further studies using ILS should address this issue. Although the internal reliability of learning satisfaction was quite high (over .9), the validity, especially construct validity, remains unclear. Future study can investigate this direction. Finally, it is unclear that how students' perceptions of teaching styles match their learning styles in classrooms and to what extent this interaction impacts their learning satisfaction. By including the evaluation of teaching style as additional examining factor and using qualitative interview might untangle this relationship.

This study aims at disentangling the drivers of students' learning preferences in satisfactions of leaning. As Pratt (2002) noted, "no single view learning or teaching dominated what might be called 'good teaching"' (p. 5). This is an argument against a one-size-fits-all view of learning and teaching. The learning preferences of this sample shows that most of students were balanced learners in the A-R (Active-Reflective) and the Sq-G (Sequential-Global) dimensions. However, for the $\mathrm{Vs}-\mathrm{Vb}$ (Visual-Verbal) and the $\mathrm{S}-\mathrm{N}$ (Sensing-Intuitive) dimension, the number of students who were either in the category of balanced or moderate was quite equal. This profile of students' leaning preferences provides a useful insight for the instructor to accommodate her teaching approaches to students in order to maximize their learning outcomes. For example, the instructor might provide more visual pretentions and written instructions for the course delivery. In addition, she also needs to use more cases or scenarios to explain the main concepts and wrap up using a holistic picture of the content. 
In terms of learning satisfaction from three types of learning environments (face to face, online, and blended), the results demonstrated that students from the online course had the lowest scores of the overall learning satisfaction and instructor. It is probably that in this course (Adult Learning), the experiential learning component was a major component of the class. The essence of the experiential learning is deviated from the conventional learning methods and centers on encouraging students to explore different learning approaches in order to maximize their learning experience (Kolb, 2000). Thus, it might be a challenging task for these students who were not familiar with this teaching/learning approach. These students were assigned different projects that required them to attend formal and informal adult learning environments to determine what was encouraging and causing barriers to the participants. These projects are also used in the face to face class at the university. For many of the online students, this was as unusual approach to learning, through analyzing their experiences. Their reflections provided insight into their challenges while utilizing the theoretically based class content to assess their perceptions of their experiences.

Interestingly, according to the regression analysis, the $\mathrm{S}-\mathrm{N}$ dimension was the strongest predictor of students' learning satisfaction. Students either having moderate or strong preferences of the S-N dimension showed lower satisfaction, comparing students with a balanced presence. This finding implies that the instructor should reconsider her teaching approaches by using more concrete examples to explain the course content and covering more theories to extend the knowledge. For example, the instructor could start to use some case studies to explain main concept of the theory and then involve other theories to compare and contrast in order to demonstrate the similarities and differences. In fact, on the behavior of reflecting these findings, the professor has added simulated case studies to recent classes to explore the student needs and satisfaction.

This study is unique in that it attempts to examine the possible relationship between students' learning styles and leaning satisfaction. It is crucial for educators to recognize their students' learning preferences thereby employing different pedagogies to maximize the learning results. As this study demonstrated, profiling students' learning styles might be the first step to attain this goal.

\section{References}

Akib, I. (2013). Student learning style on mathematics through bugis-makassar culture. Indian Streams Research Journal, 3(5), 1-5.

Brookfield, S. D. (1986). Understanding and facilitating adult learning. San Francisco, CA: Jossey-Bass.

Brundage, D., Keane, R., \& Mackneson, R. (1994). Application of learning theory to the instruction of adults. In T. Barer-Stein \& J. A. Draper (Eds.), The craft of teaching adults (pp. 131-144). Malabar, FL: Krieger.

Crawford, S. Y., Alhreish, S. K., \& Popovich, N. G. (2012). Comparison of learning styles of pharmacy students and faculty members. American Journal of Pharmaceutical Education, 76(10), 1-6. http://dx.doi.org/10.5688/ajpe7610192 
Du Torr, P. H., De Boer, A., Bothma, T., \& Scheepers, D. (2012). Multidissiplinêre samewerking: 'n Noodsaaklikheid vir onderwysinnovering. (Afrikaans). Tydskrif Vir Geesteswetenskappe, 52(2), 236-251.

Felder, R. M. (1996). Matters of style. ASEE Prism, 6(4), 18-23.

Felder, R. M., Felder, G. N., \& Dietz, E. J. (2002). The effects of personality type on engineering student performance and attitudes. Journal of Engineering Education, 91(1), 3-17. http://dx.doi.org/10.1002/j.2168-9830.2002.tb00667.x

Felder, R. M., \& Henriques, E. R. (1995). Learning and teaching styles in foreign and second language education. Foreign Language Annals, 28(1), 21-31. http://dx.doi.org/10.1111/j.1944-9720.1995.tb00767.x

Felder, R. M., \& Silverman, L. K. (1988). Learning and teaching styles in engineering education. Engineering Education, 78(7), 674-681.

Felder, R. M., \& Soloman, B. A. (1997). Index of learning styles. Retrieved from http://www.ncsu.edu/felder-public/ILSpage.html

Felder, R. M., \& Spurlin, J. (2005). Applications, reliability, and validity of the index of learning styles. International Journal of Engineering Education, 21(1), 103-112.

Heimlich, J. E., \& Norland, E. (2002). Teaching style: Where are we now? New Directions for Adult and continuing education, 93, 17-25. http://dx.doi.org/10.1002/ace.46

Herrmann, N. (1990). The creative brain. Lake Lure, NC: Brain Books.

Kolb, D. A. (1984). Experimental learning: Experience as the source of learning and development. Englewood Cliffs, NJ: Prentice-Hall.

Kolb, D. A. (2000). Facilitator's guide to learning. Bostron, MA: Hay/Mcber.

Lawrence, G. (1994). People types and tiger stripes (3rd ed.). Gainesville, FL: Center for Applications of Psychological Type.

Litzinger, T. A., Lee, S. H., Wise, J. C., \& Felder, R. M. (2007). A psychometric study of the index of learning styles. Journal of Engineering Education, 96(4), 309-319. http://dx.doi.org/10.1002/j.2168-9830.2007.tb00941.x

MacKeracher, D. (2012). Making sense of adult learning (2nd ed.). Toronto, Canada: University of Toronto Press. (Kindle edition).

Manee, F., Nadar, M., \& Jahrami, H. (2013). Learning styles of allied health sciences students at Kuwait University. International Journal of Therapy \& Rehabilitation, 20(5), 255-259.

Merriam, S. B., Caffarella, R. S., \& Baumgartner, L. M. (2007). Learning in adulthood: A comprehensive guide (3rd ed.). San Francisco, CA: John Wiley \& Sons.

Nuzhat, A., Salem, R., Hamdan, N., \& Ashour, N. (2013). Gender differences in learning 


\section{Macrothink}

styles and academic performance of medical students in Saudi Arabia. Medical Teacher, 35S78-S82. http://dx.doi.org/10.3109/0142159X.2013.765545

Ogundokun, M. O. (2011). Learning style, school environment and test anxiety as correlates of learning outcomes among secondary school students. IFE Psychologia, 19(2), 321-336. http://dx.doi.org/10.4314/ifep.v19i2.69555

Palermo, C., Walker, K. Z., Brown, T., \& Zogi, M. (2009). How dietetics students like to learn: Implications for curriculum planners. Nutrition \& Dietetics, 66(2), 108-112. http://dx.doi.org/10.1111/j.1747-0080.2009.01337.x

Pratt, D. D. (2002). Good teaching: One sizes fits all? New Directions for Adult and Continuing Education, 93, 5-16. http://dx.doi.org/10.1002/ace.45

Ramayah, M., Sivanandan, P., Nasrijal, N., Letchumanan, T., \& Lim Chee, L. (2009). Preferred learning style: Gender influence on preferred learning style among business students. Journal of US-China Public Administration, 6(4), 65-78.

Shaw, R. (2012). A study of the relationships among learning styles, participation types, and performance in programming language learning supported by online forums. Computers \& Education, 58(1), 111-120. http://dx.doi.org/10.1016/j.compedu.2011.08.013

Sternberg, R. J. (1997). Thinking styles. New York, NY: Cambridge University Press. http://dx.doi.org/10.1017/CBO9780511584152

Weng, P. (2012). The effect of learning styles on learning strategy use by EFL learners. Journal of Social Sciences, 8(2), 230-234. http://dx.doi.org/10.3844/jssp.2012.230.234

\section{Copyright Disclaimer}

Copyright reserved by the author(s).

This article is an open-access article distributed under the terms and conditions of the Creative Commons Attribution license (http://creativecommons.org/licenses/by/3.0/). 